\title{
BEBERAPA MASALAH DALAM PENGIMPLEMENTASIAN KEWAJIBAN NEGARA INDONESIA DI BAWAH PERJANJIAN INTERNASIONAL KE DALAM HUKUM NASIONAL INDONESIA
}

\author{
I Wayan Parthiana \\ email: iwayanparthiana@gmail.com
}

\begin{abstract}
s
Indonesia had been involved in the making of quite a number of international treaties and had also ratified a certain number of treaties. The State's international obligations and rights stipulated by those treaties at a certain point must be implemented by and through the national legal system. Two issues identified are how to situate or place international treaties within the hierarchal order of the Indonesian legislation and, secondly, how those international rights and obligations (as found in treaties) should be harmonized (and incorporated) into the national legal system. The author shall present a general overview of those issues and offer some recommendations for change.
\end{abstract}

Keywords:

international law, national law, treaties, national legislations, interaction.

\begin{abstract}
Abstrak
Indonesia sudah banyak membuat dan meratikasi perjanjian internasional dan selanjutnya hak dan kewajiban internasional di bawah perjanjian internasional harus direspon oleh dan melalui hukum nasional. Dua masalah yang dapat diidentifikasi adalah tentang penempatan perjanjian internasional yang sudah diratifikasi ke dalam tata urutan perundang-undangan dan selanjutnya bagaimana hak dan kewajiban Negara Indonesia yang dituangkan dalam perjanjian internasional harus diselaraskan dengan aturan-aturan di tataran hukum nasional. Tulisan ini akan memberikan ulasan umum tentang kedua persoalan di atas dan memberikan sejumlah saran perubahan.
\end{abstract}

Kata Kunci:

hukum internasional, hukum nasional, perjanjian internasional, peraturan perundang-undangan nasional, interaksi.

\section{Pendahuluan}

Dalam era globalisasi, interaksi antara hukum internasional dan hukum nasional negara-negara ataupun antara sesama hukum nasional negara-negara berlangsung dengan intensif dan dinamis ${ }^{1}$. Ada negara atau kelompok negara yang hukum nasionalnya begitu kuat pengaruhnya terhadap perkembangan hukum internasional ataupun hukum nasional negara-negara lain. Sebaliknya ada negara

1 Dalam buku-buku teks tentang hukum Internasional, masalah ini dibahas tersendiri dalam satu Bab dengan judul: Hubungan antara Hukum Internasional dan Hukum Nasional. Lihat dan baca misalnya, Mochtar Kusumaatmadja: Pengantar Hukum Internasional; Boer Mauna: Hukum Internasional; Pengertian, Peranan dan Fungsi dalam Era Dinamika Global, J. G. Starke, Q. C.: Introduction to International Law; Ian Brownlie: Principles of Public International Law dan masih banyak lagi yang lain. 
yang hukum nasionalnya (sebagai cerminan kepentingan nasional) tidak begitu berpengaruh terhadap perkembangan hukum internasional ataupun hukum nasional negara lain. Ini berarti, bahwa secara politis atau dari kacamata hubungan internasional, interaksi tersebut berlangsung secara tidak simetris. Faktor yang berpengaruh, antara lain, adalah tingkat kemajuan negara-negara di dunia ini yang tidak merata. Semakin maju dan kuat suatu negara atau kelompok negara yang lazim disebut negara-negara maju (developed countries), semakin kuat pengaruh hukum nasionalnya terhadap perkembangan hukum internasional ataupun hukum nasional negara-negara lain. Demikian pula sebaliknya. Akan tetapi, dalam hal-hal tertentu, negara-negara yang kurang maju (negara-negara sedang berkembang atau developing countries), jika bersatu, dapat juga mempengaruhi perkembangan hukum internasional. Kini sudah ada bidangbidang hukum internasional yang berkembang akibat dampak tekanan dan pengaruh kelompok negara-negara ini² $^{2}$.

Interaksi asimetris negara berkembang dan negara maju, secara khusus tercermin dalam perjanjian-perjanjian internasional dan peraturan perundangundangan nasional yang dibuat sebagai respon terhadap kewajiban negara yang ditegaskan dalam perjanjian-perjanjian tersebut. Tidak jarang terdapat perjanjian internasional yang substansinya berasal dari (atau norma yang dirumuskan dalam) peraturan perundang-undangan nasional negara-negara dan sebaliknya juga tidak jarang substansi peraturan perundang-undangan nasional negaranegara diambil dari dan berasal dari perjanjian-perjanjian internasional. Bahkan, juga terjadi negara-negara melalui metode perbandingan hukum, mengadopsi peraturan perundang-undangan negara lain, mengenai suatu masalah tertentu, untuk selanjutnya dijadikan substansi dari peraturan perundang-undangan nasionalnya mengenai masalah sejenis.

2 Sebagai contoh, substansi Konvensi Hukum Laut PBB 1982 (the 1982 United Nations Convention on the Law of the Sea) sebagian adalah hasil perjuangan negara-negara sedang berkembang. Demikian pula instrumen-instrumen hukum perdagangan internasional dalam kerangka World Trade Organisation (WTO) juga berkat perjuangan negara-negara sedang berkembang. 
Pembentukan hukum nasional Indonesia pun tidak terlepas dari pengaruh interaksi intensif dan dinamis dengan hukum internasional maupun hukum negara-negara lain. Interaksi ini mulai terjadi semenjak Indonesia semakin intensif terlibat dalam hubungan-hubungan internasional, terutama pada era 1950-an, setelah berhasil mengakhiri revolusi fisik dari 1945 sampai 1949. Bahkan pada jaman penjajahan Belanda pun, sebenarnya interaksi semacam ini sudah terjadi, meskipun tidak seintensif dan sedinamis sekarang ini. Dewasa ini, peraturan perundang-undangan Indonesia sudah ada (walaupun belum banyak) yang diterima sebagai substansi dari suatu konvensi internasional. Demikian pula sebaliknya, sudah tidak terhitung lagi substansi perjanjian-perjanjian internasional yang kemudian diadopsi dan ditransformasi menjadi ketentuan dalam peraturan perundang-undangan nasional Indonesia, yang sebagian bahkan sebagian besar dilakukan melalui pemberlakuan perjanjian internasional itu ke dalam hukum nasional Indonesia. Sudah tentu dengan segala konsekuensi hukumnya. Tulisan ini akan menelusuri permasalahan hukum yang muncul dari interaksi timbal-balik perjanjian internasional (konvensi-konvensi yang diratifikasi Indonesia) dengan perkembangan hukum nasional Indonesia. Persoalan-persoalan yang diungkap diharapkan dapat menjadi titik tolak untuk mempelajari pengaruh dan dampak hukum internasional (terutama perjanjian internasional) pada pengembangan hukum nasional Indonesia.

\section{Gambaran Umum tentang Perjanjian Internasional}

Hukum internasional dewasa ini maupun pada masa yang akan datang, sebagian besar terdiri dari perjanjian internasional. Subyek-subyek hukum internasional pada umumnya, negara-negara pada khususnya, cenderung mengatur masalah-masalah internasional dan kesepakatan tentang bagaimana mereka harus meresponsnya dalam bentuk perjanjian-perjanjian internasional. Kecenderungan ini terutama disebabkan oleh bentuknya yang tertulis dan sekaligus dengan itu derajat kepastian hukumnya yang sangat tinggi.

Di dunia ini, terdapat banyak sekali perjanjian internasional. Bahkan diprediksi akan bertambah terus pada masa-masa yang akan datang. Perjanjian 
internasional yang demikian banyaknya itupun dapat ditinjau dari pelbagai segi, seperti, substansi, obyek yang diatur, pihak yang menjadi pemrakarsa, proses perumusan, jumlah peserta atau pihak, saat mulai berlakunya, ruang lingkup berlakunya, sifat dari kaidah hukum yang dikandung, jangka waktu berlakunya, bahasa yang digunakan dalam perumusan, dan lain-lain. Bahkan satu perjanjian internasional, dapat ditinjau dari pelbagai segi tersebut. Dengan kata lain, perjanjian internasional itu bersifat multidimensional.

Demikian pula penamaan atau penyebutan (nomenclature) untuk pelbagai macam perjanjian internasional itu ternyata juga bermacam-macam. Baik dalam bahasa Inggris maupun Indonesia dapat kita temukan ragam penamaan, seperti; treaty (traktat), convention (konvensi), charter (piagam), covenant (kovenan), statute (statuta), declaration (deklarasi), agreement (persetujuan), arrangement (penetapan, penataan), protocol (protokol), pact (pakta), act (akta, akte), memorandum of understanding (memorandum kesepahaman), dan masih ada lagi sebutan lain yang agak jarang dipakai dalam praktik. Penggunaan nama atau sebutan ini pun dalam praktiknya tidak mengenal ukuran baku. Dengan kata lain, digunakan secara acak sesuai kepentingan dan kesepakatan para pihak ketika melakukan perundingan dalam rangka merumuskan substansinya. Walaupun sebaliknya ada beberapa penamaan atau penyebutan yang tampak menunjukkan keseragaman dalam penggunaannya. Tetapi itu hanyalah merupakan kecenderungan (trends) saja, bukan sesuatu yang sudah baku sebagai hukum positif.

Apa yang lebih penting diperhatikan di sini adalah kenyataan bagaimanapun juga perjanjian internasional adalah hasil proses politik. Kenyataan ini, antara lain tampak dari kesepakatan para pihak untuk membuatnya yang dilatarbelakangi dan didorong oleh adanya kepentingan politik dari masingmasing pihak. Kesepakatan ini dilanjutkan dengan proses perundingan sampai dengan dihasilkan naskah final perjanjian. Kemudian dikonkretkan dengan persetujuan terikat serta dinyatakan mulai mengikat dan berlaku sebagai hukum (internasional) positif. Dengan kata lain, persoalan politik yang berwujud kepentingan (nasional) subyektif masing-masing pihak (negara-negara) yang pada 
akhirnya mencapai titik temu dan menjadi kepentingan bersama yang bertransformasi menjadi hukum (internasional) positif dalam wujud perjanjian internasional.

Perjanjian internasional dalam hal ini muncul sebagai hasil kesepakatan (kompromi) antara para subyek hukum internasional yang berkedudukan sama derajat. Artinya tidak dibuat dan diberlakukan oleh badan internasional global yang berkedudukan supranasional (yang memang tidak pernah ada di dalam masyarakat internasional yang strukturnya koordinatif). ${ }^{3}$ Konsekuensi dari itu, perjanjian internasional tidak berada di atas masyarakat internasional, melainkan berada di antara atau di tengah-tengah masyarakat internasional. Itu sebabnya, hukum internasional pada umumnya, perjanjian internasional pada khususnya, disebut sebagai hukum yang bersifat koordinatif. Sebagai hukum koordinatif, pelaksanaan (implementation) dan penaatan (enforcement) sepenuhnya tergantung pada kehendak bebas masing-masing subyek hukum internasional, khususnya negara-negara yang merdeka-berdaulat. Dalam beberapa kasus, kadang terjadi pelanggaran oleh salah satu pihak tanpa pihak lain dapat mengambil tindakan atau sanksi apapun terhadap negara yang bersangkutan. Inilah yang menyebabkan hukum internasional, termasuk perjanjian internasional, disebut hukum yang lemah (weak law).

Sebagai konsekuensi dari masyarakat dan hukum internasional yang bersifat koordinatif, sumber hukum internasional (perjanjian internasional sebagai bagian dari hukum internasional dengan pelbagai nama atau sebutan, termasuk di dalamnya), tidak mengenal hierarkhi sebagaimana halnya peraturan perundang-undangan nasional negara-negara. Semua sumber hukum internasional, termasuk satu perjanjian dengan perjanjian lain, berkedudukan setara, meskipun ditinjau dari bobot substansinya terdapat perbedaan yang cukup besar. Dalam beberapa perjanjian internasional, tidaklah mudah untuk

3 Di dunia ini, badan supra nasional ini yang diakui eksistensinya hanyalah yang bersifat regional, yakni, Uni Eropah (European Union). The European Union is therefore neither an international organisation in the usual sense nor an association of States, but rather an autonomous entity somewhere in between the two. In legal circles, the term "supranational" organisation is now used (European Union Pocket Guide). 
menyatakan suatu perjanjian internasional bertentangan dengan perjanjian internasional yang lain, bahkan juga tidak mudah untuk menentukan apakah suatu perjanjian internasional yang lama (dibuat lebih dahulu) bertentangan dengan yang muncul kemudian.

Dalam hukum perjanjian internasional, kepentingan negara-negara pihak/peserta dengan kedaulatannya masing-masing, diakomodasi dengan memberikan hak pada negara-negara tesebut untuk menolak ataupun memberikan pengertian lain atas ketentuan tertentu dari perjanjian internasional berdasarkan atas kepentingan subyektif dari negara itu sendiri. Inilah yang lebih dikenal dengan sebutan pensyaratan (reservation) yang pada hakekatnya merupakan tindakan sepihak (unilateral act). Terhadap pensyaratan ini, negaranegara pihak/peserta lain yang juga memiliki kedaulatan, juga diberikan hak untuk menyetujui ataupun menolak/keberatan terhadap pensyaratan yang diajukan oleh salah satu negara pihak/peserta. Bahkan semua negara pihak/peserta yang memberikan/membuat atau menerima/menolak pensyaratan juga diberikan hak untuk menarik kembali pensyaratannya ataupun menarik kembali penolakan terhadap pensyaratan tersebut dengan segala konsekuensi hukumnya. Semua itu harus dipandang sebagai manifestasi pengakuan hukum perjanjian internasional atas kedaulatan negara.

Selain pensyaratan, dalam praktik hubungan internasional, terutama setelah mulai berlakunya Konvensi Wina 1969 (tentang perjanjian internasional antara negara) dan Konvensi Wina 1986 (tentang perjanjian internasional antara negara dengan Organisasi Internasional atau antara Organisasi Internasional, baik sebagai perjanjian yang mengikat maupun hukum kebiasaan internasional), dikenal apa yang disebut deklarasi atau pernyataan (declaration) terhadap suatu ketentuan dari suatu perjanjian internasional. Deklarasi ini tumbuh dan berkembang dalam praktik-praktik hukum perjanjian internasional. Kedua Konvensi sama sekali tidak mengaturnya. Hampir sama dengan pensyaratan, deklarasi pun merupakan tindakan sepihak. Bedanya adalah deklarasi tidak membutuhkan persetujuan ataupun penolakan dari negara-negara pihak/peserta lainnya. Apa konsekuensi hukum maupun dampak dari deklarasi ini, belum 
banyak dikaji oleh para ahli. Demikian pula yurisprudensi (hukum internasional) berkenaan dengan deklarasi ini boleh dikatakan sangat jarang atau tidak ada sama sekali.

Kedua pranata hukum di atas (pensyaratan dan deklarasi) tidak dikenal di dalam hukum atau peraturan perundang-undangan nasional. Alasannya adalah sistem hukum nasional merupakan hukum sub-ordinatif. Hukum nasional, khususnya peraturan perundang-undangan nasional, dibuat oleh suatu badan nasional atau lembaga negara yang status hukumnya lebih tinggi dari subyeksubyek hukum nasional dan keberlakuannya dapat dipaksakan bahkan dengan ancaman pengenaan sanksi.

\section{Gambaran Umum tentang Peraturan Perundang-Undangan Nasional Indonesia}

Negara sebagai pribadi hukum (legal persons) dengan kedaulatan yang melekat pada dirinya, memiliki yurisdiksi (hak, kekuasaan ataupun kewenangan) melalui badan-badan atau organ pemerintahnya untuk mengatur (yang meliputi pembuatan, pelaksanaan dan pemaksaan peraturan perundang-undangan) terhadap segala sesuatu yang ada atau terjadi di dalam batas-batas ruang lingkup yurisdiksi nasional. Dengan demikian, peraturan perundang-undangan dapat dipandang sebagai produk hukum yang dibuat, dilaksanakan dan dipaksakan oleh negara itu sendiri melalui pemerintahnya sebagai salah satu unsur negara. Ini menunjukkan, pemerintah berkedudukan setingkat lebih tinggi dari subyeksubyek hukum yang terdapat di dalam batas-batas ruang lingkup yurisdiksi nasionalnya. Atas dasar itu, hukum atau peraturan perundang-undangan nasional dipandang sebagai hukum yang bersifat subordinatif dan dapat dipaksakan berlakunya oleh negara. Proses pembuatan, pelaksanaan dan pemaksaannya sudah tertata sedemikian jelas, tegas dan pasti demi terwujudnya kepastian hukum bagi semua subyek hukum yang ada di dalam yurisdiksi nasional negara itu. Dalam jangka panjang, hal ini dimaksudkan demi terwujudnya tujuan negara, yakni: keamanan, ketertiban, ketentraman, kedamaian, dan keadilan bagi rakyatnya. 
Peraturan perundang-undangan sebagai bagian dari hukum nasional, dibuat, diberlakukan, dilaksanakan dan dipaksakan oleh badan-badan pemerintah sesuai dengan hierarkhi dan kewenangannya masing-masing. Misalnya, di Indonesia, Undang-Undang Dasar dibuat dan ditetapkan oleh Majelis Permusyawaratan Rakyat, Undang-Undang oleh Presiden bersama Dewan Perwakilan Rakyat, Peraturan Pemerintah pengganti Undang-Undang ditetapkan oleh Presiden, Peraturan Pemerintah (untuk melaksanakan Undang-Undang) dan Peraturan Presiden oleh Presiden, sedangkan Peraturan Daerah (tingkat provinsi atau kabupaten/kota dan desa) ditetapkan kepala daerah bersama-sama perangkat perwakilan daerah di wilayah yang bersangkutan. ${ }^{4}$

Lembaga atau badan-badan pemerintah tersebut, tersusun secara hierarkhi dari yang tertinggi hingga terendah. Demikian pula masing-masing peraturan perundang-undangan, seturut dengan apa yang diaturnya (umum-khusus), tersusun secara hierarkhi dengan bobot substansi yang berbeda-beda. Sebagai konsekuensi dari adanya hierarkhi tersebut, menjadi penting dan perlu diatur bagaimana perhubungan antara peraturan perundang-undangan yang berkedudukan lebih tinggi maupun antar peraturan perundang-undangan yang berada pada satu tataran, tergantung dari waktu pembuatan maupun substansi pengaturannya. Jika terjadi konflik atau pertentangan antara satu dengan lainnya, dengan relatif mudah dapat disimpulkan, bahwa yang satu akan dikalahkan atau dikesampingkan oleh yang lain. Dalam ilmu hukum, ada tiga asas yang secara tegas menjawabnya, yakni; lex superiori derogat legi inferiori, lex specialis derogat legi generali dan lex posteriori derogat legi priori.

Suatu peraturan perundang-undangan yang sudah disahkan dan diberlakukan, mengikat subyek-subyek hukum yang tunduk pada yurisdiksi nasional negara itu. Jika ada yang menolak atau keberatan, disediakan saluran untuk mengklaim badan pemerintah yang bersangkutan melalui badan yudikatif yang berwenang memeriksa dan memutuskan klaim tersebut dengan putusan yang berkekuatan mengikat yang tetap/pasti. Dalam sistem hukum nasional

\footnotetext{
${ }^{4}$ Lihat dan baca pasal 7 Undang-Undang Republik Indonesia Nomor 12 Tahun 2011 tentang Pembentukan Peraturan Perundang-Undangan.
} 
Indonesia, upaya ini dapat ditempuh melalui Mahkamah Konstitusi, Mahkamah Agung ataupun Pengadilan Tata Usaha negara sesuai dengan kewenangan masingmasing.

Selanjutnya harus disadari, bahwa hukum nasional suatu negara, termasuk hukum nasional Indonesia, mencakup pula perjanjian-perjanjian internasional (memuat hak dan kewajiban hukum yang langsung dibebankan pada negara atau yang langsung memberikan hak pada warganegara) yang diberlakukan oleh hukum nasional Indonesia melalui mekanisme tertentu sebagaimana diatur di dalam peraturan perundang-undangan Indonesia. Selain melalui ratifikasi di atas, ketentuan dalam perjanjian internasional dapat pula diadopsi langsung oleh pembuat Undang-Undang Indonesia dan dengan itu seketika menjadi bagian dari hukum nasional. Pengadopsian ini bisa dilakukan terhadap seluruh, sebagian atau beberapa ketentuan dari perjanjan internasional tersebut.

Persoalannya di sini adalah bagaimana proses ratifikasi dan adopsi mengubah ketentuan-ketentuan dalam perjanjian internasional menjadi norma di tataran hukum nasional Indonesia? Dengan kata lain, bagaimana sebenarnya interaksi perjanjian internasional (yang mengikat negara) dengan peraturan perundang-undangan (yang dibuat dan diberlakukan oleh negara Indonesia)?

\section{Pengaturan Ratifikasi Perjanjian Internasional}

Ketika berbicara mengenai dasar hukum kewenangan negara untuk membuat dan meratifikasi perjanjian internasional serta memberlakukan ketentuan-ketentuan di dalamnya ke dalam hukum nasional Indonesia (atau menyatakannya sebagai bagian dari hukum nasional), para ahli hukum Indonesia, akan berpaling pada Undang-Undang Dasar 1945 sebagai peraturan perundangundangan di puncak hierarkhi hukum Indonesia. Pada umumnya pasal yang dijadikan sebagai dasar hukum adalah Pasal 4 (1) yang memuat norma umum tentang kekuasaan pemerintahan Di samping itu, juga dirujuk ketentuan Pasal 11 yang substansinya lebih khusus. Sebab secara tegas mengatur kewenangan membuat perjanjian internasional, walaupun masih digabung dengan pengaturan mengenai perang dan perdamaian. 
Selengkapnya pasal 4 ayat 1 menyatakan sebagai berikut:

Presiden Republik Indonesia memegang kekuasaan pemerintahan menurut Undang-Undang Dasar.

Seperti diketahui, kekuasaan pemerintahan itu demikian luasnya. Secara garis besar, kekuasaan pemerintahan meliputi pemerintahan yang berkenaan dengan masalah dalam negeri dan masalah luar negeri yang juga populer dengan hubungan luar negeri atau hubungan internasional. Masing-masing negara mengatur sendiri hubungan luar negeri di dalam hukum nasionalnya. Misalnya, Indonesia mengatur dengan Undang-Undang, yakni, Undang-Undang Nomor 37 Tahun 1999 tentang Hubungan Luar Negeri.

Sedangkan mengenai perjanjian internasional, ditegaskan dalam pasal 11 (lama) Undang-Undang Dasar 1945 yang digabungkan dengan pernyataan perang dan membuat perdamaian dengan negara lain. Tegasnya, ketentuan Pasal 11 menyatakan:

Presiden dengan persetujuan Dewan Perwakilan Rakyat menyatakan perang, membuat perdamaian dan perjanjian dengan negara lain.

Pasal 11 ini barulah menyentuh sisi luar dari perjanjian internasional, yakni, pembuatannya bersama dengan negara lain yang harus mendapat persetujuan Dewan. Sedangkan belum diatur masalah setelahnya, yaitu pemberlakuan ketentuan-ketentuan perjanjian internasional ke dalam hukum nasional. Jika dikatakan tampak, hanyalah secara tersimpul, yakni, perlu adanya persetujuan Dewan sebagai lembaga negara pembuat Undang-Undang bersamasama dengan Presiden. Dengan kata lain, perjanjian yang dibuat oleh Presiden dengan negara lain yang sudah mendapat persetujuan Dewan, harus diberlakukan ke dalam hukum nasional dengan Undang-Undang sebagai produk bersama Dewan dan Presiden.

Berkenaan dengan pembuatan perjanjian (internasional), seperti yang diatur menurut Pasal 11 ini, Dewan Perwakilan Rakyat pada 1960 (setelah berlakunya kembali Undang-Undang Dasar 1945 melalui Dekrit Presiden 5 Juli 
1959) harus menjawab suatu masalah, yakni, apakah Presiden dalam setiap membuat perjanjian internasional dengan negara lain harus mendapat persetujuan Dewan? Masalah ini ditanyakan oleh Ketua Dewan kepada Presiden dalam bentuk sebuah surat. Presiden menjawab dalam bentuk surat, yang kemudian dikenal dengan nama, Surat Presiden Nomor: 2826/HK/1960, 22 Agustus 1960. Isi pokok dari Surat Presiden ini adalah:

“............ perjanjian-perjanjian yang lazimnya berbentuk treaty yang mengandung materi sebagai berikut:

a. Soal-soal politik atau soal-soal yang dapat mempengaruhi haluan politik luar negeri Negara seperti halnya dengan perjanjianperjanjian persahabatan, perjanjian-perjanjian persekutuan (aliansi), perjanjian-perjanjian tentang perubahan wilayah atau penetapan tapal batas.

b. Ikatan-ikatan yang sedemikian rupa sifatnya sehingga mempengaruhi haluan politik luar negari Negara; dapat terjadi bahwa ikatan-ikatan sedemikian dicantumkan di dalam perjanjian kerjasama ekonomi dan teknis atau pinjaman uang.

c. Soal-soal yang menurut Undang-undang Dasar atau menurut sistim perundang-undangan kita harus diatur dengan Undangundang, seperti soal-soal kewarganegaraan dan soal-soal kehakiman.

Perjanjian-perjanjian yang mengandung materi yang lain yang lazimnya berbentuk agreement akan disampaikan kepada Dewan Perwakilan Rakyat hanya untuk diketahui setelah disahkan oleh Presiden.

Sebagai sebuah surat, Surat Presiden ini status hukumnya sama saja dengan surat antara dua individu ataupun dua badan hukum, hanya merupakan urusan kedua pihak. Akan tetapi karena menyangkut dua lembaga tinggi negara dan obyeknya mengenai masalah ketatanegaraan, Surat Presiden ini diperlakukan secara khusus oleh para penyelenggara negara, khususnya oleh kedua lembaga tinggi negara tersebut, yakni, Presiden dan Dewan. Surat Presiden ini dalam praktik pembuatan dan pemberlakuan perjanjian internasional, dijadikan sebagai acuan normatif yang mengikat. Bahkan pada masa Orde Baru sampai dengan masa awal Orde Reformasi, dijadikan sebagai dasar hukum dalam pembuatan dan pemberlakuan perjanjian internasional. Surat Presiden ini tampak sudah lebih jelas berkenaan dengan pemberlakuan perjanjian internasional yang dibuat 
bersama dengan negara lain ke dalam hukum nasional Indonesia, baik mengenai substansinya maupun mengenai bentuk hukum atau peraturan perundangundangannya. Surat Presiden ini membedakan dua macam perjanjian internasional berdasarkan substansinya, yakni:

a. Perjanjian internasional yang harus mendapat persetujuan Dewan sehingga perjanjian internasional itu merupakan hasil kesepakatan antara Presiden dan Dewan yang kemudian diberlakukan (disahkan dan diundangkan) dengan Undang-Undang;

b. Perjanjian internasional yang tidak membutuhkan persetujuan Dewan dan karena itu pemberlakuannya hanya dengan Keputusan Presiden.

Surat Presiden ini tidak secara tegas menyatakan bentuk peraturan perundang-undangan mengenai pemberlakuan ketentuan perjanjian internasional ke dalam atau dalam hukum nasional. Hal ini hanya dapat disimpulkan dari bunyi Surat Presiden itu yang selanjutnya dalam praktik ketatanegaraan Indonesia dibedakan menjadi dua macam. Hal ini berlangsung selama masa Orde lama (1960-1967) sampai Orde Baru (1967-1998) bahkan terus berlaku pada masa awal Orde Reformasi (1998-2000).

Masih berkaitan dengan praktik ketatanegaraan, khususnya dalam pembuatan, peratifikasian dan pemberlakuan ketentuan-ketentuan perjanjian internasional, kemudian tumbuh dan berkembang perjanjian internasional jenis yang ketiga yakni, perjanjian internasional yang dapat langsung diberlakukan sebagai bagian dari hukum nasional Indonesia. Perjanjian internasional jenis ini, begitu ditandatangani oleh wakil-wakil para pihak sebagai bukti persetujuannya, secara langsung diberlakukan (dianggap bagian dari sistem hukum nasional Indonesia) pada saat itu juga, dalam bentuk Undang-Undang ataupun Keputusan Presiden. Pada umumnya, substansinya berkenaan dengan masalah-masalah yang lebih bersifat teknis operasional. Tentu saja selama masa berlakunya Surat Presiden tersebut, jumlah dan macamnya sudah tak terhitung lagi. Sampai pada derajat tertentu, tumbuh dan berkembangnya perjanjian internasional jenis ketiga di atas memang dapat dimengerti karena demikian intensif dan rumitnya 
hubungan-hubungan internasional sehingga dibutuhkan kecepatan dalam pembuatan dan pemberlakuannya.

Baru setelah memasuki masa Orde Reformasi, dibuat Undang-Undang pelaksanaan dari Pasal 11 Undang-Undang Dasar 1945, yakni, Undang-Undang Nomor 24 Tahun 2000 tentang Perjanjian Internasional. Pembedaan atas pemberlakuan perjanjian internasional ke dalam ketiga golongan ini, ternyata diadopsi bahkan dipertegas oleh Undang-Undang Nomor 24 Tahun 2000, sebagaimana dapat dijumpai dalam pasal 10,11 ayat 1 dan 2, serta pasal 15 ayat 1 yang masing-masing rumusannya sebagai berikut:

Pasal 10:

Pengesahan perjanjian inernasional dilakukan dengan undangundang, apabila berkenaan dengan:

a. Masalah politik, perdamaian, pertahanan dan keamanan negara;

b. Perubahan wilayah atau penetapan batas wilayah negara Republik Indonesia;

c. Kedaulatan atau hak berdaulat negara;

d. Hak asasi manusia dan lingkungan hidup;

e. Pembentukan kaidah hukum baru;

f. Pinjaman dan/atau hibah luar negeri.

Pasal 11 ayat 1 dan 2:

(1) Pengesahan perjanjian internasial yang materinya tidak termasuk materi sebagaimana dimaksud pasal 10, dilakukan dengan keputusan presiden;

(2) Pemerintah Republik Indonesia menyampaikan salinan setiap keputusan presiden yang mengesahkan suatu perjanjian internasional kepada Dewan Perwakilan Rakyat untuk dievaluasi.

Pasal 15 ayat 1 :

Selain perjanjian internasional yang perlu disahkan dengan undangundang atau keputusan presiden, Pemerintah Republik Indonesia dapat membuat perjanjian internasional yang berlaku setelah penandatanganan atau pertukaran dokumen perjanjian/nota diplomatik, atau melalui cara-cara lain sebagaimana disepakati oleh para pihak pada perjanjian tersebut.

Perlu diketahui, Undang-Undang Nomor 24 Tahun 2000, masih berlandaskan atau merujuk pada ketentuan Pasal 11 (lama). Sebab pada waktu Perubahan Pertama (tahun 1999) Undang-Undang Dasar 1945, ketentuan ini tidak 
termasuk yang diubah. Ketentuan Pasal 11 baru diubah dalam Perubahan Ketiga (2001) dan Keempat (2002) dengan penambahan ayat 2 dan 3, sehingga pasal 11 yang semula tidak ada ayatnya diubah menjadi tiga ayat, dimana naskah lama menjadi ayat 1 ditambah dengan ayat 2 dan 3 , yang rumusan selengkapnya adalah:

1. Presiden dengan persetujuan Dewan Perwakilan Rakyat menyatakan perang, membuat perdamaian dan perjanjian dengan negara lain.

2. Presiden dalam membuat perjanjian internasional lainnya yang menimbulkan akibat yang luas dan mendasar bagi kehidupan rakyat yang terkait dengan beban keuangan negara, dan/atau mengharuskan perubahan atau pembentukan undang-undang harus dengan persetujuan Dewan Perwakilan Rakyat.

3. Ketentuan lebih lanjut tentang perjanjian internasional diatur dengan undang-undang.

Namun, Undang-Undang Nomor 24 Tahun 2000 ini masih tetap terus diberlakukan hingga kini, meskipun Pasal 11 Undang-Undang Dasar 1945 sebagai landasan hukumnya sudah mengalami perubahan. Praktik Indonesia pun dalam pembuatan, peratifikasian dan pemberlakuan perjanjian internasional selama ini masih tetap berlandaskan pada Undang-Undang Nomor 24 Tahun 2000.

Pertanyaan lanjutan dapat dimunculkan di sini: mengapa suatu perjanjian internasional yang notabene merupakan kesepakatan antar negara, jadi bersifat internasional, perlu diberlakukan ke dalam dan (ketentuan-ketentuannya) dijadikan sebagai bagian dari hukum nasional (Indonesia)?

Alasannya adalah karena pada akhirnya rakyatlah (dari negara penandatangan Perjanjian Internasional) yang menerima dan menikmati hak dan memikul kewajiban yang bersumber dari perjanjian internasional itu. Karena itu, sudah sewajarnya rakyat tahu substansi pengaturan perjanjian internasional dan bagaimana pemerintah memberlakukan ke dalam dan menjadikannya sebagai bagian dari hukum nasional (Indonesia). Setelah menjadi bagian dari hukum nasional, rakyat dapat mencari dan menemukannya, misalnya, di dalam Lembaran Negara Republik Indonesia (LNRI) sebagai tempat pengundangannya. Dengan demikian, rakyat dapat mencari tahu dan mendapatkan informasi tentang 
substansi perjanjian internasional tertentu yang sudah diratifikasi atau dengan cara lain disetujui pemerintah untuk menjadi bagian dari kewajiban negara di tataran internasional. Ini sesuai dengan adagium, bahwa setiap orang dianggap mengetahui hukum.

Di samping itu, dalam era globalisasi dan transparansi seperti sekarang ini, interaksi antara hukum internasional dan hukum nasional pada umumnya, antara perjanjian internasional dan peraturan perundang-undangan nasional pada khususnya, tidak terkecuali Indonesia, berlangsung secara intensif dan dinamis dengan segala implikasinya. Dengan memberlakukan ketentuan-ketentuan dalam perjanjian internasional - yang sebelumnya sudah diratifikasi - ke dalam hukum nasional Indonesia, maka interaksi tersebut dapat diketahui dengan lebih jelas dan dengan demikian penyikapan terhadap perjanjian internasional itupun dapat dilakukan dengan lebih kritis.

\section{Implementasi Pasal 11 (1, 2 \& 3) Undang-Undang Dasar 1945 dan Undang- Undang Nomor 24 Tahun 2000 tentang Perjanjian Internasional}

Ketentuan Pasal 11 Undang-Undang Dasar 1945 yang sudah diubah menjadi ketentuan Pasal 11 (1, 2, \& 3), serta Surat Presiden Nomor 2826/HK/1960 selama masa berlakunya dari 1960-2000, demikian pula UndangUndang Nomor 24 Tahun 2000 sudah menegaskan kriteria dari suatu perjanjian internasional yang harus diberlakukan (disahkan dan diundangkan) dengan Undang-Undang ataupun dengan Keputusan Presiden (sekarang: Peraturan Presiden), serta adanya perjanjian internasional yang diberlakukan secara langsung. Namun dalam praktiknya tetap menimbulkan pelbagai masalah, baik teoritis maupun praktis. Beberapa masalah tersebut, antara lain:

a. Ketentuan Pasal 11 ayat 1 (naskah semula, naskah lama) Undang-Undang Dasar 1945 yang rumusannya sangat umum menimbulkan pelbagai persoalan. Salah satunya sudah dijawab oleh Surat Presiden Nomor 2826/HK/1960. Meskipun kemudian tetap mengandung masalah tersendiri. Tampaknya, Majelis Permusyawaratan Rakyat yang berwenang mengubahnya, menafsirkan pasal 11 ayat 1 tersebut bersifat fakultatif. Artinya terbuka pilihan boleh 
dengan persetujuan Dewan ataupun boleh juga tidak. Atas dasar itulah, dimunculkan ketentuan Pasal 11 (2) yang sifatnya imperatif. Ketentuan ini menyatakan bahwa Presiden dalam membuat perjanjian internasional lainnya harus (melakukannya) dengan persetujuan Dewan Perwakilan Rakyat. Jadi pemberlakuan (pengesahan dan pengundangnya) ke dalam hukum nasional Indonesia harus dengan undang-undang. Timbul pertanyaan, "perjanjian internasional lainnya" yang manakah yang dimaksudkan oleh ketentuan Pasal 11 (2) ini? Jawabannya, perjanjian internasional selain dari yang dimaksudkan oleh Pasal 11(1). Perjanjian internasional manakah itu? Sama sekali tidak jelas. Pasal 11 (1) itu sendiri tidak menegaskan. Substansinyapun masih sangat umum, sebab hanya menegaskan tentang pembuatan perjanjian internasional dengan negara lain. Namun ketentuan Pasal 11(2) menjelaskan kriteria dari perjanjian internasional yang dibuat oleh Pemerintah yang harus mendapat persetujuan Dewan, yakni; a) perjanjian internasional yang menimbulkan akibat yang luas dan mendasar bagi kehidupan rakyat yang terkait dengan beban keuangan negara; b) perjanjian internasional yang mengharuskan perubahan atau pembentukan Undang-Undang. Pertanyaan lanjutannya adalah apakah perjanjian-perjanjian internasional yang substansinya sangat besar dan penting tetapi berada di luar dari dua kriteria Pasal 11(2) tidak membutuhkan persetujuan Dewan? Bukankah di luar dari kedua kriteria ini masih banyak ada perjanjian-perjanjian internasional yang substansinya besar dan penting walaupun tidak menimbulkan akibat yang luas dan mendasar bagi kehidupan rakyat?

b. Ketentuan Pasal 11 (2) Undang-Undang Dasar 1945 dihubungkan dengan pasal 10 Undang-Undang Nomor 24 Tahun 2000 menentukan 6 (enam) kriteria kapan suatu perjanjian internasional harus disahkan dengan UndangUndang. Kriteria ini ternyata tidak jauh berbeda ruang lingkupnya dengan pasal 11 (2) Undang-Undang Dasar 1945. Salah satu yang sangat jelas tampak adalah butir/huruf f dari pasal 10 Undang-Undang Nomor 24 Tahun 2000, yaitu pinjaman dan/atau hibah luar negeri. Hal ini tentu saja erat hubungannya dengan beban keuangan negara sebagaimana secara eksplisit 
dinyatakan dalam pasal 11 (2). Dengan kata lain, terjadi tumpang tindih antara pasal 11 (2) Undang-Undang Dasar 1945 dengan pasal 10 butir a-f Undang-Undang Nomor 24 Tahun 2000. Pasal 11 (2) (khususnya mengenai "beban keuangan negara") inipun bertumpang tindih dengan Bab VIII (Hal Keuangan), tegasnya pasal 23C yang menyatakan, hal-hal lain mengenai keuangan negara diatur dengan Undang-Undang. Dengan adanya tumpang tindih ini, patut dipertanyakan, apakah pasal 11(2) (Perubahan) UndangUndang Dasar 1945 masih relevan untuk dipertahankan? Bukankah substansinya itu sudah cukup diatur dalam Undang-Undang yang tentu saja lebih mudah diubah dan disesuaikan dengan perkembangan jaman?

c. Meskipun Surat Presiden Nomor 2826/HK/2960 sudah menentukan tiga kriteria suatu perjanjian internasional yang untuk pembuatannya harus dimintakan persetujuan Dewan dan karena itu pemberlakuan (pengesahan dan pengundangannya) harus dengan Undang-Undang, sedangkan perjanjian internasional yang di luar dari 3 (tiga) kriteria ini pengesahannya dengan keputusan presiden, dalam praktik selama masa berlakunya (1960-2000), masih saja terjadi penyimpangan. Perjanjian internasional yang seharusnya dimintakan persetujuan Dewan, ternyata tidak dimintakan persetujuan Dewan dan karena itu disahkan dengan keputusan/peraturan presiden. Sebagai contoh adalah perjanjian-perjanjian tentang penghindaran/penghapusan pajak berganda (agreement on the avoidance of double taxation) antara Indonesia dengan negara-negara sahabat yang diberlakukan dengan keputusan presiden. Demikian pula sebaliknya, pernah ada sebuah perjanjian internasional yang substansinya bersifat teknis operasional, tetapi diberlakukan dengan Undang-Undang (diajukan oleh Pemerintah kepada Dewan untuk mendapat persetujuan), yakni, Perjanjian tentang Celah Timor antara Indonesia dan Australia pada tahun 1991 yang diberlakukan dengan Undang-Undang Nomor 1 Tahun $1991 .^{5}$

5 Nama lengkap dari perjanjian ini adalah: Treaty between the Republic of Indonesia and Australia on the Zone of Cooperation in an Area between the Indonesian Province of East Timor and Northern Australia. Diberlakukannya Perjanjian ini dengan undang-undang (bukan dengan 
Kekeliruan pemberlakuan suatu perjanjian internasional yang seharusnya dengan Undang-Undang tetapi dengan Peraturan Presiden masih terjadi dalam masa berlakunya Undang-Undang Nomor 24 Tahun 2000 tentang Perjanjian Internasional, yakni, Pengesahan Convention on Mutual Administrative Assistance in Tax Matters (Konvensi tentang Bantuan Timbal Balik dalam bidang Administrasi Perpajakan). Pengesahannya seharusnya dilakukan dengan Undang-Undang, tetap dalam kenyataannya dilakukan dengan Peraturan Presiden Nomor 159 Tahun 2014. Bukankah masalah administrasi perpajakan adalah bagian dari masalah perpajakan dan perpajakan adalah bagian dari hal keuangan (vide Bab VIII Hal Keuangan, pasal 23B dan 23 C Undang-Undang Dasar 1945).

d. Kekeliruan dalam pemberlakuan (pengesahan dan pengundangan) menimbulkan dampak berantai. Perjanjian internasional yang substansinya sebenarnya setara dengan substansi Undang-Undang, namun karena disahkan dengan keputusan presiden, dalam hierarkhi peraturan perundang-undangan Indonesia mendapat tempat yang dua tingkat lebih rendah dari UndangUndang. Demikian pula sebaliknya, perjanjian internasional yang seharusnya diberlakukan dengan keputusan presiden tetapi diberlakukan dengan Undang-Undang. Artinya secara hierarkhi mendapat tempat dua tingkat lebih tinggi dari Keputusan Presiden.

e. Pemberlakuan perjanjian internasional ke dalam dua bentuk hierarkhi peraturan perundang-undangan inipun patut dipersoalkan. Mengapa hanya dalam dua bentuk ini saja? Bukankah ada perjanjian internasional yang substansinya setara dengan Undang-Undang Dasar 1945, dengan Peraturan Pemerintah, ataupun dengan Keputusan Menteri? Bahkan persoalan lebih mendasar dapat diajukan: apakah tepat perjanjian internasional yang karakternya berbeda dengan peraturan perundang-undangan nasional, yakni

keputusan presiden), tampaknya disebabkan karena dimensi politiknya yang sangat tinggi dari pihak Indonesia, yakni, harapan Indonesia untuk mendapat pengakuan dari Australia atas masuknya Timor Timur sebagai bagian wilayah Indonesia sebab Australia sebagai negara tetangga dekat Indonesia, menentang atau tidak mengakui penggabungan Timur Timur sebagai bagian wilayah Indonesia. 
tidak mengenal hierarkhi kemudian ditransformasikan menjadi UndangUndang dan Keputusan/Peraturan Presiden (yang mengenal hierarkhi)?

f. Perjanjian internasional yang seharusnya diberlakukan (disahkan dan diundangkan) dengan Undang-Undang karena bobot substansinya setara dengan Undang-Undang tetapi ternyata diberlakukan dengan Keputusan/Peraturan presiden memunculkan persoalan dalam perujukannya di dalam pembuatan perundang-undangan nasional, terutama berkaitan dengan pengisian konsideran "Mengingat". Sebagai contoh, Konvensi tentang Hak Anak, 1989 (Convention on the Rights of the Child of 1989), setelah diratifikasi kemudian disahkan dengan Keputusan Presiden (Keputusan Presiden Nomor 36 Tahun 1990). Ketika Pemerintah Indonesia akan membuat Undang-Undang tentang hak anak, Undang-Undang tentang perlindungan anak, Undang-Undang tentang kesejahteraan anak, yang semuanya merupakan turunan dari Konvensi tentang Hak Anak, ternyata bukan Keputusan Presidennya yang dijadikan konsiderans "Mengingat" melainkan Konvensi tentang Hak Anak itu secara langsung. Masih berhubungan dengan Konvensi Hak Anak, 1989, dua protokol turunannya, yakni, Protokol Opsional Konvensi Hak Anak mengenai Keterlibatan Anak dalam Konflik Bersenjata (Optional Protocol to the Convention on the Rights of Child on the Involvment of Childern in Armed Conflict) dan Protokol Opsional Konvensi Hak Anak mengenai Penjualan Anak, Prostitusi Anak, dan Pornografi Anak (Optional Protocol to the Convention on the Rights of the Child on the Sale of Childern, Child Prostitution and Child Pornography), ternyata masing-masing diberlakukan (disahkan dan diundangkan) dengan Undang-Undang tersendiri, yakni, Undang-Undang Nomor 9 Tahun 2012 dan Undang-Undang Nomor 10 Tahun 2012. Ini merupakan kejanggalan sebab perjanjian induknya diberlakukan (disahkan dan diundangkan) dengan Undang-Undang sedangkan dua protokol turunannya dengan Undang-Undang.

g. Masalah selanjutnya adalah, jika konvensi yang diberlakukan dengan Keputusan Presiden tersebut (seharusnya dengan Undang-Undang) dinyatakan bertentangan dengan Undang-Undang Dasar 1945, apakah 
merupakan kewenangan (jika memang berwenang) Mahkamah Konstitusi ataukah Mahkamah Agung? Ditinjau dari substansinya yang setara dengan Undang-Undang, tentulah menjadi kewenangan dari Mahkamah Konstitusi. Akan tetapi karena pemberlakuannya dengan Keputusan Presiden, tentulah menjadi kewenangan dari Mahkamah Agung. Hal yang sebaliknya juga bisa terjadi. Persoalan ini cukup dilematis.

h. Masih berkenaan dengan uji konstitusional dan uji materiil, ada perjanjian internasional bilateral seperti, perjanjian-perjanjian tentang garis batas landas kontinen antara Indonesia dengan negara-negara tetangga, yang pada masa berlakunya Surat Presiden Nomor 2826/HK/1960 atau sebelum berlakunya Undang-Undang Nomor 24 Tahun 2000, diberlakukan dengan Keputusan Presiden. Sedangkan perjanjian yang obyeknya sama (landas kontinen), setelah berlakunya Undang-Undang Nomor 24 Tahun 2000, diberlakukan dengan Undang-Undang, sebab landas kontinen termasuk hak-hak berdaulat negara (vide pasal 10 huruf c Undang-Undang Nomor 24 Tahun 2000). Jika salah satu atau lebih ketentuan dari perjanjian garis batas landas kontinen yang diberlakukan dengan Keputusan Presiden (sebelum Undang-Undang Nomor 24 Tahun 2000) dipersoalkan keabsahannya, apakah harus diajukan ke Mahkamah Agung? Sebaliknya jika salah satu atau lebih ketentuan (yang substansinya sama) dari perjanjian tentang garis batas landas kontinen yang diberlakukan dengan Undang-Undang (setelah berlakunya Undang-Undang Nomor 24 Tahun 2000), apakah harus diajukan ke Mahkamah Konsitusi? Jika jawaban atas kedua persoalan tersebut positif, boleh jadi akan timbul persoalan baru, bagaimana jika putusan dari kedua Mahkamah tersebut bertentangan?

\section{Implikasi Instrumen Pernyataan Berlaku Perjanjian Internasional Terhadap (hierakhi dan keberlakuan) Peraturan Perundang-Undangan Nasional Indonesia}

Suatu perjanjian internasional yang sudah diberlakukan ke dalam dan menjadi bagian dari hukum nasional Indonesia (terutama yang dinyatakan 
berlaku dengan Undang-Undang), berlaku sebagai hukum positif nasional secara berdampingan dengan peraturan perundang-undangan nasional Indonesia. Patut dipahami, bahwa suatu perjanjian internasional mempunyai karakteristik yang sangat berbeda dengan peraturan perundang-undangan nasional. Sebagai hukum yang berasal dari luar yurisdiksi nasional negara, atau sebagai hukum pendatang, perjanjian internasional itu di samping berdampingan, juga bersinggungan dengan dan karena itu akan berimplikasi terhadap hukum atau peraturan perundangundangan nasional Indonesia.

Apa dan bagaimana saja implikasinya itu? Di bawah ini akan dipaparkan satu per satu dari beberapa implikasinya tersebut secara kasuistis. Artinya, setiap perjanjian internasional harus dilihat satu per satu.

Apabila suatu perjanjian internasional dalam kategori tertentu, misalnya, yang substansinya adalah tentang kejahatan atau tindak pidana, dan pengaturan tentang itu tidak atau belum termuat dalam peraturan perundang-undangan nasional negara yang bersangkutan, negara tersebut wajib mentransformasikan substansi dari perjanjian internasional itu menjadi Undang-Undang pidana nasionalnya. Misalnya, Indonesia ketika meratifikasi tiga Konvensi tentang Kejahatan Penerbangan pada tahun 1976 dan selanjutnya memberlakukan (mengesahkan dan mengundangkan) dengan Undang-Undang Nomor 2 Tahun 1976, ternyata belum memiliki Undang-Undang tindak pidana penerbangan. Sebab itu kemudian pemerintah mengintegrasikan ketentuan pidana penerbangan tersebut ke dalam Kitab Undang-Undang Hukum Pidana. Dalam hubungan dengan kejahatan terorisme, Indonesia sudah meratifikasi dan memberlakukan beberapa konvensinya ke dalam dan menjadi bagian dari hukum nasional Indonesia, namun hingga kini belum ditransformasikan menjadi Undang-Undang pidananya6 ${ }^{6}$.

Bagaimana perjanjian internasional dapat berimplikasi terhadap hukum atau peraturan perundang-undangan nasional Indonesia dapat dipaparkan sebagai berikut:

6 Beberapa contoh konvensi yang berkenaan dengan terrorisme adalah: International Convention for the Suppression of Acts of Nuclear Terrorisme; International Convention for the Suppression of the Financing of Terrorism; International Convention for the Suppression of Terrorist Bombings, 1997; ASEAN Convention on Counter Terrorism. 
a. Dalam hal peraturan perundang-undangannya sudah ada sebelumnya, negara yang meratifikasi perjanjian internasional kemudian harus menyelaraskan peraturan perundang-undangan nasional dengan apa yang diatur (dan disepakati) dalam perjanjian internasional itu. Antara lain, dengan melakukan amandemen atas ketentuan-ketentuan undang-undang tersebut. Hal ini didasarkan pada asumsi, bahwa kesepakatan yang tertuang dalam perjanjian internasional itu lebih mutakhir dibandingkan dengan pengaturan dalam peraturan perundang-undangan nasional. Sebagai contoh, Indonesia setelah meratifikasi dan kemudian memberlakukan Konvensi PBB Anti Korupsi, 2003 dengan Undang-Undang Nomor 7 Tahun 2006, kemudian melanjutkan dengan langkah menyelaraskan substansi undang-undang tindak pidana korupsinya (Undang-Undang Nomor 31 Tahun 1999). Apabila ketidaksesuaian itu demikian besar, maka patut dipertimbangkan apakah pemerintah tidak sebaiknya memutuskan membuat undang-undang yang baru untuk menggantikan undang-undang yang lama.

b. Jika perjanjian internasional itu substansinya mengenai masalah global dan merupakan perpaduan antara kaidah-kaidah hukum yang merupakan hukum kebiasaan internasional dan kaidah-kaidah hukum yang baru tumbuh dan berkembang7 , bahkan merupakan perombakan secara total atas kaidah-kaidah hukum yang berlaku sebelumnya, negara yang bersangkutan setelah meratifikasi dan memberlakukan perjanjian internasional itu ke dalam hukum nasionalnya, mau tidak mau harus juga melakukan perombakan total kaidahkaidah hukum nasionalnya mengenai masalah yang sama. Contoh aktual adalah dalam bidang hukum laut. Indonesia sebagai sebuah negara kepulauan, telah meratifikasi Konvensi Hukum Laut PBB 1982 pada 1985 dan memberlakukan (mengesahkan dan mengundangkan) dengan Undang-Undang Nomor 17 Tahun 1985. Sebagai konsekuensinya, Indonesia harus merombak secara total peraturan perundang-undangannya dalam bidang hukum laut

7 Pasal 13 ayat 1 huruf a dari Piagam PBB yang menyatakan sebagai berikut: The General Assembly shall initiate studies and make recommendations for the purpose of: a. promoting international cooperation in the political field and encouraging the progressive development of international law and its codifications. 
yang dahulu dibuat berdasarkan pada Konvensi Hukum Laut Jenewa 1958 yang sudah digantikan Konvensi Hukum Laut 1982.

c. Berkaitan dengan perjanjian-perjanjian internasional dalam bidang-bidang lain, seperti, ekonomi, lingkungan hidup, hak asasi manusia dan lain-lain, mungkin ada substansinya yang harus diperlakukan sama seperti perjanjian dalam bidang hukum pidana dan hukum laut seperti tersebut di atas. Mungkin juga sebagian substansinya bisa diimplementasikan secara langsung. Dalam hal inilah perlunya setiap perjanjian yang sudah diratifikasi dan kemudian diberlakukan ke dalam hukum nasional Indonesia, dikaji secara mendalam, terutama apa dan bagaimana dampaknya terhadap hukum atau peraturan perundang-undangan nasional Indonesia dalam bidang yang sama atau sejenis.

d. Bagaimana dengan perjanjian internasional yang pemberlakuannya dengan keputusan/peraturan presiden? Karena perjanjian internasional semacam ini pada umumnya (secara teoritis) bobot substansinya tergolong lebih ringan dan lebih bersifat teknis-operasional ketimbang perjanjian internasional yang diberlakukan dengan Undang-Undang - jika tidak ada kekeliruan dalam pemberlakuannya, seperti Konvensi tentang Hak Anak, 1989 tersebut di atas implikasinya tidaklah sebesar perjanjian internasional yang diberlakukan dengan Undang-Undang. Apalagi jika substansi pengaturan perjanjian internasional itu bisa langsung diimplementasikan di dalam ruang lingkup yurisdiksi nasional dari negara yang bersangkutan. Misalnya, perjanjianperjanjian tentang kerjasama dalam bidang perdagangan, pendidikan, kebudayaan, ilmu pengetahuan dan teknologi, dengan negara-negara sahabat yang semuanya diberlakukan dengan Keputusan/Peraturan Presiden. Implikasi dari pemberlakuan perjanjian internasional itu akan berada pada tataran teknis-operasional. Sebaliknya, ada pula perjanjian internasional yang diberlakukan dengan Keputusan Presiden yang ternyata berdampak luas terhadap kehidupan rakyat banyak. Perjanjian internasional tersebut adalah, Framework Agreement on Comprehensif Economic Co-operation between the Association of South East Asian Nations and the People's Republic of China, 4 November 2002 yang diberlakukan dengan Keputusan Presiden Republik 
Indonesia Nomor 48 Tahun 2004. Akibat dari pemberlakuan perjanjian di atas adalah membanjirnya barang-barang buatan Tiongkok di pasaran negaranegara anggota ASEAN, termasuk Indonesia. Akibatnya banyak industri Indonesia yang kalah bersaing, terjadi pemutusan hubungan kerja yang cukup besar bahkan berdampak pada pedagang mikro, kecil dan menengah yang lazim disebut usaha mikro, kecil dan menengah (UMKM).

e. Bagaimana dengan perjanjian internasional yang diberlakukan secara langsung? Dengan kata lain, tidak dengan Undang-Undang ataupun Keputusan/Peraturan Presiden? Secara teoritis, substansi perjanjian internasional semacam ini lebih kecil atau lebih ringan ketimbang yang diberlakukan dengan Keputusan/Peraturan Presiden, apalagi dibandingkan dengan perjanjian internasional yang diberlakukan dengan Undang-Undang. Karena sifatnya yang sangat teknis-operasional, tentu saja implikasinya terhadap peraturan perundang-undangan nasional yang lain dapat dikatakan sangat kecil, bahkan tidak ada sama sekali. Tetapi jika ada cukup banyak perjanjian-perjanjian internasional (bilateral) semacam ini yang substansinya sama atau hampir sama, bisa jadi akan berimplikasi pada bidang kehidupan yang berkenaan dengan substansi perjanjian internasional tersebut. Sebagai contoh misalnya, Indonesia membuat perjanjian-perjanjian dengan negaranegara sahabat mengenai impor garam (Indonesia sebagai pengimpor). Hal ini akan berdampak buruk terhadap produksi dan harga garam rakyat dan lebih jauh lagi menurunkan tingkat kesejahteraan rakyat.

\section{Pelaksanaan Perjanjian Internasional di dalam Yurisdiksi Nasional Indonesia}

Persoalan pokok dalam hubungan ini adalah, bagaimanakah pelaksanaan suatu perjanjian internasional dalam yurisdiksi nasional Indonesia? Sebenarnya untuk beberapa macam perjanjian internasional, jawaban atas persoalan ini sedikit sudah tersimpul dari uraian di atas. Namun demi lebih jelasnya, masalah ini akan dibahas lebih mendalam dalam bagian ini. 
Dalam praktik, tidak mudah menjawabnya, sebab ada banyak bentuk maupun macam dari perjanjian internasional yang masing-masing memiliki karakter maupun mengandung bobot substansi yang berbeda-beda. Karena itu, pendekatan secara kasuistis lebih tepat untuk digunakan. Tegasnya, setiap perjanjian internasional harus ditelaah lebih dahulu secara mendalam, apakah bisa diberlakukan secara langsung ataukah tidak, apakah membutuhkan peraturan perundang-undangan untuk menstransformasikan substansinya lebih dahulu dan dengan demikian, peraturan perundang-undangan inilah yang dilaksanakan.

Di samping itu, ada perjanjian internasional yang beberapa ketentuannya yang harus ditransformasikan lebih dahulu dan ada pula beberapa ketentuannya yang lain dapat dilaksanakan secara langsung. Demikian pula, apakah substansinya itu ada yang merupakan kaidah hukum kebiasaan internasional ataukah ada yang merupakan hasil pengembangan progresif dari hukum internasional? Ada juga perjanjian internasional yang substansinya terdiri dari bagian-bagian yang berbeda-beda, seperti, Konvensi PBB tentang Kejahatan Transnasional Terorganisasi, 2000 dan Konvensi PBB Anti Korupsi, 2003 yang masing-masing terdiri dari dua bagian besar, yaitu, pertama, bagian yang materiil-substansial seperti kejahatan atau tindak pidananya itu sendiri yang hanya dapat diterapkan jika substansinya ditransformasikan lebih dahulu menjadi ketentuan pidana dalam Undang-Undang pidana materiil dan kedua, yang formalprosedural, seperti ekstradisi, kerjasama timbal balik dalam masalah pidana, kerjasama antara aparat penegak hukum, kerjasama pengembalian aset dan lainlain. Ketentuan-ketentuan prosedural (teknik-operasional) tersebut secara langsung dapat diterapkan baik pada tataran internasional ataupun nasional/domestik.

Meskipun pendekatan kasuistis lebih memadai, namun dibutuhkan beberapa acuan yang dapat digunakan untuk menelaah pelaksanaan suatu perjanjian internasional di dalam ruang lingkup yurisdiksi nasional suatu negara, termasuk Indonesia. Beberapa acuan tersebut, antara lain: 
a. Perjanjian-perjanjian internasional dalam bidang hukum pidana (materiil ataupun formal atau penggabungan dari keduanya di dalam satu perjanjian internasional). Misalnya, konvensi-konvensi tentang kejahatan internasional atau transnasional, seperti konvensi tentang kejahatan penerbangan, konvensi tentang tindak pidana perdagangan orang, tindak pidana pencucian uang, dan lain-lain, haruslah ditransformasikan lebih dahulu menjadi Undang-Undang pidana nasional atau jika undang-undangnya sudah ada sebelumnya, substansi Undang-Undang itu harus diselaraskan dengan substansi konvensi. Hal ini berhubungan dengan asas legalitas dalam hukum pidana. Sedangkan konvensikonvensi yang berkenaan dengan hukum pidana internasional formalprosedural, seperti tentang ekstradisi, bantuan timbal balik dalam masalah pidana, kerjasama antara aparat penegak hukum, pengembalian aset, dapat dilaksanakan secara langsung di dalam yurisdiksi nasional, meskipun belum ada Undang-Undang nasional yang mengaturnya.

b. Perjanjian-perjanjian internasional dalam bidang hak asasi manusia, dapat diterapkan secara langsung. Sebab hak asasi manusia itu melekat pada setiap individu, termasuk individu yang berada di dalam ruang lingkup yurisdiksi nasional tanpa perlu ada peraturan perundang-undangan nasional yang secara khusus mengaturnya. Misalnya, konvensi tentang penghapusan segala bentuk diskriminasi ras, konvensi tentang penghapusan diskriminasi terhadap wanita, kovenan tentang hak-hak sipil dan politik, kovenan tentang hak-hak ekonomi, sosial dan budaya.

c. Perjanjian internasional yang substansinya merupakan perpaduan antara pengkodifikasian dan pengembangan progresif hukum internasional. Konvensi semacam ini, terutama kaidah-kaidah hukumnya yang berupa hukum kebiasaan internasional dapat dilaksanakan secara langsung dalam yurisdiksi nasional negara-negara, termasuk Indonesia. Sedangkan yang merupakan perkembangan progresif yang tentu saja relatif baru, sepanjang sebagai hukum yang formal-prosedural, juga dapat dilaksanakan secara langsung tanpa menunggu pengaturannya dalam peraturan perundang-undangan nasional. 
d. Perjanjian internasional yang substansinya sepenuhnya merupakan perumusan kaidah-kaidah hukum internasional baru sebagai konsekuensi dari kemajuan sains dan teknologi. Sebagai contoh adalah, Treaty Banning Nuclear Weapon Tests in the Atmosphere, in the Outer Space and Under Water of August 5, 1963; Convention on International Liability for Damage Caused by Space Objects of November 29, 1971; Treaty on Principles Governing the Activities of States in the Exploration and Use of Outer Space, including the Moon and Other Celestial Bodies of January 27, 1967. Dimensi internasional perjanjian semacam ini tampak sangat besar sedangkan dimensi nasional/domestiknya sangat kecil. Karena itu pelaksanaan hak dan kewajiban negara di bawah perjanjian internasional seperti ini bobotnya lebih besar pada tataran internasional ketimbang domestik. Apakah perjanjian semacam ini perlu ditransformasikan menjadi Undang-Undang nasional? Jika memang negara yang bersangkutan memandang perlu dan penting tentu langkah ini yang akan diambil.

e. Perjanjian internasional yang beberapa pasal atau ketentuannya membutuhkan adanya perundang-undangan nasional sebagai peraturan pelaksanaan sedangkan beberapa pasal atau ketentuannya yang lain dapat dilaksanakan secara langsung (langsung membebankan hak dan kewajiban pada negara). Apakah ketentuan suatu perjanjian internasional membutuhkan peraturan perundang-undangan pelaksana lebih dahulu ataukah tidak (dapat dilaksanakan secara langsung), tergantung pada pertimbangan dari (pemerintah) negara itu sendiri.

f. Perjanjian internasional yang substansinya teknis operasional. Perjanjian semacam ini pada dasarnya secara langung dapat dilaksanakan di dalam yurisdiksi nasional. Namun jika pemerintah negara itu memandang perlu melengkapi dengan peraturan perundang-undangan pelaksanaannya tentulah bisa saja dilakukan. Misalnya, perjanjian kerjasama perdagangan antara warganegara di wilayah perbatasan yang dalam pelaksanaannya membutuhkan pembangunan pasar tradisional bersama atau pembangunan pintu gerbang perbatasan. Untuk itu, masing-masing negara membutuhkan anggaran. Kebutuhan anggaran itulah yang diatur di dalam surat Keputusan 
Menteri yang berwenang ataupun peraturan kepala daerah di wilayah perbatasan dari masing-masing pihak.

g. Perjanjian internasional yang diberlakukan secara langsung. Karena diberlakukan secara langsung tentu saja perjanjian semacam ini tidak membutuhkan peraturan perundang-undangan pelaksanaan.

\section{Perundang-Undangan Nasional Indonesia yang Bertentangan dengan Hukum Internasional Umum}

Bisa saja terjadi peraturan perundang-undangan nasional Indonesia baik yang merupakan pentransformasian ataupun pelaksanaan dari perjanjianperjanjian internasional umum yang sudah diratifikasi dan diberlakukan ke dalam dan menjadi bagian dari hukum nasional Indonesia, ternyata bertentangan dengan hukum internasional umum tersebut. Pertanyaan pertama yang harus diajukan adalah bertentangan dengan hukum internasional umum yang mana dan yang bagaimana? Jika bertentangan dengan kaidah hukum atau perjanjian internasional umum yang tergolong ius cogens, secara absolut ketentuan peraturan perundangundangan nasional itu batal demi hukum. Jika Indonesia menyadari hal ini, sudah seharusnya Indonesia menyatakan ketentuan peraturan perundang-undangannya itu tidak berlaku, atau menggantinya dengan substansi yang baru yang tidak bertentangan dengan ius cogens tersebut. Sebagai contoh, Indonesia sudah meratifikasi Konvensi Wina 1961 tentang Hubungan Diplomatik dan memberlakukan (mengesahkan dan mengundangkan) dengan Undang-Undang Nomor 1 Tahun 1982. Dalam transformasi ketentuan-ketentuan perjanjian internasional ke dalam dan menjadi Undang-Undang tentang hubungan diplomatik (sampai kini Indonesia belum memiliki Undang-Undang yang dimaksudkan), ternyata ada satu pasal yang tidak mengakui hak-hak istimewa dan kekebalan diplomatik yang diatur di dalam Konvensi tersebut. Ketentuan pasal semacam ini jelas dan tegas bertentangan dengan kaidah-kaidah hukum tentang hak istimewa dan kekebalan diplomatik yang diatur dalam Konvensi yang memang jauh sebelumnya sudah diakui sebagai hukum kebiasaan internasional 
umum bahkan sudah dipandang sebagai jus cogens. Pasal ini harus dipandang batal demi hukum.

Jika ketentuan hukum nasional ternyata bertentangan dengan suatu kaidah hukum atau perjanjian internasional yang substansinya tidak tergolong ius cogens atau sebagai hukum internasional positif biasa, maka pemerintah bebas menentukan sikapnya sendiri. Jika negara (Indonesia) ingin tetap mempertahankan ketentuan peraturan perundang-undangan nasionalnya, tentu hal itu merupakan hak dari negara itu sendiri. Sudah tentu dengan segala konsekuensi hukum yang timbul sebagai akibat dari pertentangan tersebut. Jika negara itu bermaksud untuk mengubah atau menggantinya, itupun merupakan haknya. Secara ideal, pengubahan atau penggantian tersebut dapat mewujudkan keharmonisan dengan kaidah hukum internasional atau perjanjian internasional tersebut. Misalnya, di kawasan Asia Tenggara telah terbentuk konvensi regional tentang perikanan. Pada lain pihak, Indonesia jauh sebelumnya sudah memiliki Undang-Undang tentang perikanan. Kemudian baru belakangan diketahui bahwa, salah satu atau lebih pasal dari Undang-Undang perikanan Indonesia tersebut bertentangan dengan salah satu pasal dari konvensi. Dalam hal ini, terserah kepada Indonesia dalam menyikapinya. Sikap apapun yang diambil oleh Indonesia, sudah tentu ada konsekuensi hukum yang harus dipikulnya.

Jika peraturan perundang-undangan nasional merupakan transformasi ataupun merupakan pelaksanaan dari suatu perjanjian internasional, yang ternyata bertentangan dengan substansi dari perjanjian internasional itu sendiri, masalahnya sama saja seperti di atas. Semua dikembalikan kepada negara itu sendiri, dalam hal ini, termasuk Indonesia. Umpamanya, Indonesia sudah meratifikasi dan memberlakukan konvensi tentang terorisme dan kemudian mentransformasikan menjadi Undang-Undang tindak pidana terorisme. Akan tetapi ruang lingkup terorisme di dalam Undang-Undang nasionalnya tersebut jauh lebih luas ketimbang ruang lingkup terorisme dalam konvensi. Apapun konsekuensi hukum yang ditimbulkan dari masalah ini sepenuhnya menjadi tanggung jawab negara itu sendiri. 
Namun, masalahnya kadang-kadang tidak sesederhana itu. Dalam praktik, boleh jadi hal ini menimbulkan masalah yang merugikan seseorang atau sekelompok orang ataupun badan hukum di dalam yurisdiksi nasional negara yang bersangkutan. Masalah ini selanjutnya berkembang menjadi sengketa hukum (nasional atau internasional). Pihak yang dirugikan akan menempuh upaya hukum berupa penyelesaian sengketa ke hadapan badan peradilan nasional dari negara itu dan menggugat keabsahan peraturan perundang-undangan nasional yang bertentangan dengan perjanjian internasional (memuat ketentuan tentang kewajiban Negara Indonesia).

Beberapa pertanyaan yang dapat dimunculkan di sini ialah apakah pengadilan nasional Indonesia berwenang memeriksa atau menguji keabsahan peraturan perundang-undangan nasional terhadap perjanjian internasional? Jika pengadilan berpendapat bahwa undang-undang itu bertentangan dengan ketentuan suatu perjanjian internasional, apakah pengadilan berwenang menyatakan Undang-Undang itu tidak sah dan mengenyampingkan penerapannya? Jika pengadilan berpendapat sebaliknya, yakni, ketentuan suatu perjanjian internasional dipandang bertentangan dengan ketentuan UndangUndang, apakah pengadilan berwenang mengenyampingkan ketentuan perjanjian internasional tersebut? Persoalan lain, apakah pengadilan nasional (Indonesia) berwenang menjadikan perjanjian internasional sebagai dasar ataupun rujukan dalam memeriksa dan memutuskan suatu perkara yang sedang dihadapinya? Masalah-masalah ini membutuhkan pengkajian yang secara lebih mendalam melalui suatu penelitian ilmiah tersendiri.

\section{Penutup}

Berdasarkan pembahasan di atas, dapatlah ditarik beberapa butir kesimpulan sebagai berikut:

a. Selain adanya perbedaan karakter antara hukum internasional dan hukum nasional, terdapat pula perbedaan yang cukup bervariasi antara karakter perjanjian internasional sebagai bagian dari hukum internasional dan peraturan perundang-undangan nasional sebagai bagian dari hukum nasional. 
Terlepas dari perbedaan karakter itu, ditengarai keduanya (hukum internasional dan hukum nasional Indonesia) tetap berinteraksi secara progresif dan dinamis. Satu wujud interaksi muncul dalam masuk dan berlakunya ketentuan-ketentuan dalam perjanjian internasional ke dalam sistem hukum nasional. Sebaliknya ketentuan-ketentuan dalam hukum nasional dapat berkembang dan diangkat ke tataran internasional dan menjadi bagian dari hukum internasional.

b. Sistem hukum nasional Indonesia juga mempengaruhi dan dipengaruhi hukum internasional. Dalam konteks ini persoalan yang dihadapi Indonesia adalah bagaimana menempatkan perjanjian internasional dalam tata urutan perundang-undangan yang bersifat hierarkhis dan bagaimana memberlakukan ketentuan-ketentuan dalam perjanjian internasional ke dalam dan melalui hukum nasional Indonesia.

c. Semua masalah yang ditimbulkan dari pemberlakuan perjanjian internasional tidak bisa didekati secara umum dan melainkan harus didekati secara kasuistis. Andaikata pun harus didekati secara umum, itu pun harus dirinci lagi secara lebih konkret. Tetapi kesimpulan yang ditarik tetap hanya berlaku sebagai acuan tidak mengikat.

d. Berkaitan dengan semua itu, maka dalam rangka amandemen UUD 1945, pasal 11 (2) (Perubahan) Undang-Undang Dasar 1945 menurut hemat penulis dihapus. Alasannya adalah untuk menghindari tumpang tindih dengan pengaturan ketentuan Pasal 23 (Hak Keuangan) Undang-Undang Dasar 1945 maupun dengan ketentuan Pasal 10 Undang-Undang Nomor 24 Tahun 2000 tentang Perjanjian Internasional.

e. Undang-Undang Nomor 24 Tahun 2000 tentang Perjanjian Internasional juga perlu diganti dengan Undang-Undang yang baru sebab Undang-Undang ini mengandung banyak kelemahan seperti yang sudah diuraikan di atas. 


\section{Daftar Pustaka}

Buku:

Boer Mauna, Hukum Internasional: Pengertian, Peranan dan Fungsi dalam Era Dinamika Global, Edisi Pertama, Alumni, Bandung, 2000.

Mochtar Kusumaatmadja, Pengantar Hukum Internasional, Jilid I, Bagian Umum, Binacipta, Bandung, 1982.

J. G. Starke, Q. C., Introduction to International Law, Butterworths, London, Seventh Edition, 1972.

Ian Brownlie, Principles of Public International Law, Third Edition, Oxford University Press, Oxford, 1973.

I Wayan Parthiana, Hukum Perjanjian Internasional, Bagian Pertama, Edisi Revisi, Mandar Maju, Bandung,

Mandar Maju. Bandung

, Hukum Laut Internasional dan Hukum Laut Indonesia, Cetakan

Pertama, Yrama Widya, Bandung, 2014

--------------, Landas Kontinen dalam Hukum Laut Internasional, Edisi Revisi, Mandar Maju, Bandung, 2015.

Mark E. Villiger, Customary International Law and Treaties; A Study of Their Interactions and Interrelations with Special Consideration of the 1969 Vienna Convention on the Law of Treaties, Martinus Nijhoff Publishers, Dordrecht/Boston/Lancaster, 1985.

Joseph Modeste Sweeney et. al., Documentary Supplement to Cases and Materials on International Legal System, Second Edition, The Foundationi Press Inc, Mineola, New York, 1981.

\section{Peraturan Perundang-Undangan}

Undang-Undang Dasar Republik Indonesia 1945

Undang-Undang Republik Indonesia Nomor 37 Tahun 1999 tentang Hubungan Luar Negeri

Undang-Undang Republik Indonesia Nomor 24 Tahun 2000 tentang Perjanjian Internasional

Surat Presiden Republik Indonesia Nomor 2826/HK/1960 tentang Pembuatan Perjanjian Internasional dengan negara lain

\section{Perjanjian Internasional}

The 1969 Vienna Convention on the Law of Treaties

The 1986 Vienna Convention on the Law of Treaties between States and International Organisations or between International Organisations

The 1982 United Nations Convention on the Law of the Sea

Treaty between the Republic of Indonesia and Australia on the Zone of Cooperation in an Area between the Indonesian Province of East Timor anf Northern Australia, 1989. 